\title{
A Model for Calculating the Capacities of horrea and Agricultural Areas of Gallo-Roman villae in the Province of Germania superior
}

\author{
Lars Blöck
}

Compared with other pre-industrial societies, a rather high percentage of the Roman population in the Gallic and Germanic provinces was not involved in agrarian production during the High Empire. Rural produce was needed to feed soldiers and the inhabitants of vici, small towns and cities. To maintain this system the Gallo-Roman villae - the rural settlements whose economic base was the production of agrarian goods - had to produce a surplus of food and especially of grain. Although the villae were of fundamental importance for the Roman economy, ancient sources do not give any information about the extent of the grain production of Gallo-Roman villae.

Horrea, found among the buildings of several villae, can give us an indication about the amount of grain that was stored in a villa and therefore at the disposal of the owner. The problem is that there are no ancient data about the storage capacity of granaries in the Roman north-west provinces. The question of how the grain was stored in horrea is disputed among historians and archaeologists. Some scholars say that grain was stored in sacks, while others claim that it was stored in bulk directly on the granary floor (Rickman 1971, 85; Gentry 1976, 18; Schubert 2016, 336-38; Blöck 2016, 94 note 580). This second opinion is generally accepted. In most cases the capacity of a granary is then calculated by multiplying its inner surface area by a given height for the heap of grain. Often no explanation is offered for the height (Manning 1975, 115-18; Willems 1988, 11; Heimberg 2002-2003, 128 note 30; Schucany 2006, 197; Ferdière 2015, 39). Calculations with storage in sacks have also been put forward (Gentry 1976, 25-28; Strickland 1987; Schubert 2016, 338-47). Finally, most calculations assume that Roman horrea possessed only one floor for grain storage.

In my opinion, these calculations lack a sound basis and produce values for storage capacities that are far too high. Good insights into how Roman grain storage may have worked are offered by medieval and early modern granaries. Such buildings existed especially in monasteries but also in cities and on rural estates. Like their Roman counterparts, they served as storage spaces for grain 
produced in a pre-industrial (agrarian) setting. Since the late medieval and early modern granaries had more or less the same function and were of the same size as Roman horrea, it makes sense to take their capacity values as a reference for Roman granaries rather than using more or less random heap heights.

For early modern granaries, we possess data both on how grain was stored and on the storage capacities of granaries. So grain was to be stored in bulk in heaps no higher than $90 \mathrm{~cm}$ (fig. 1.1, see the transcription of the Early Modern High German text in Rudolf 1989a, 18; Krünitz 1788, 851). But the height of newly harvested grain heaps was even lower, from 30 to $60 \mathrm{~cm}$ (Krünitz 1788, 741, 841 and 851 ). This was necessary for proper ventilation of the grain in order to avoid decomposition and fermentation. Indeed, fermentation raises the grain temperature and may cause fires. From the medieval and early modern documentation on granaries, we also learn that space was needed for the delivery of the grain and for regularly moving it around (shovelling) in order to ensure proper ventilation (Krünitz 1788, 771-75, 789-90, 840-44; Johnson 1987, 164). Finally, these sources tell us that grain was stored in sacks only for transport (Krünitz 1788, 854-56).

Valuable data about the storage capacity of early modern granaries are to be found in the Ökonomische Encyclopedie $\left(1773^{-1786)}\right.$ edited by Johann Georg Krünitz, where the author explains how to build such a storehouse (Krünitz 1788, 789-91). An ideal granary should measure $37.67 \mathrm{~m}$ by $12.56 \mathrm{~m}$ i.e. $473.14 \mathrm{~m}^{2}$. The headroom should be between $2.51 \mathrm{~m}$ and $2.83 \mathrm{~m}$. Such a granary could contain $262.69 \mathrm{~m}^{3}$ of grain. This means that 555.21 litres of grain were stored per square metre of floor area (for the conversion of the measurements used by Krünitz into modern measurements, see Blöck 2016, 95 note 585).

Another early modern source gives us slightly different values for storage capacities, about a third higher than Krünitz's. At the end of the seventeenth century a granary, $59.34 \mathrm{~m}$ by $15.07 \mathrm{~m}$ in size, was erected in the monastery Weingarten near Lake Constance. There is an architectural sketch of this granary dated 1684 (fig. 1.1). The details of the sketch tell us that one floor with an inner surface area of $820.12 \mathrm{~m}^{2}$ could hold 3200 Weingarten Scheffel. A Weingarten $S$ cheffel is a measure of capacity corresponding to 183.65 l. This means that $716.58 \mathrm{l} / \mathrm{m}^{2}$ of grain could be stored on one floor. The headroom of the four storeys of the granary was between $2.88 \mathrm{~m}$ and $3.15 \mathrm{~m}$. So they were more or less the same height as the Krünitz granary (Rudolf $1989 \mathrm{~b}$; for the conversion of the measurements used in the early modern sketch into modern measurements, see Blöck 2016, 95 note 586).

If we take the data from the Krünitz granary and the storage capacity of the Weingarten granary respectively as the basis for estimating the capacity of Roman granaries, we get much lower storage capacities in comparison with the 


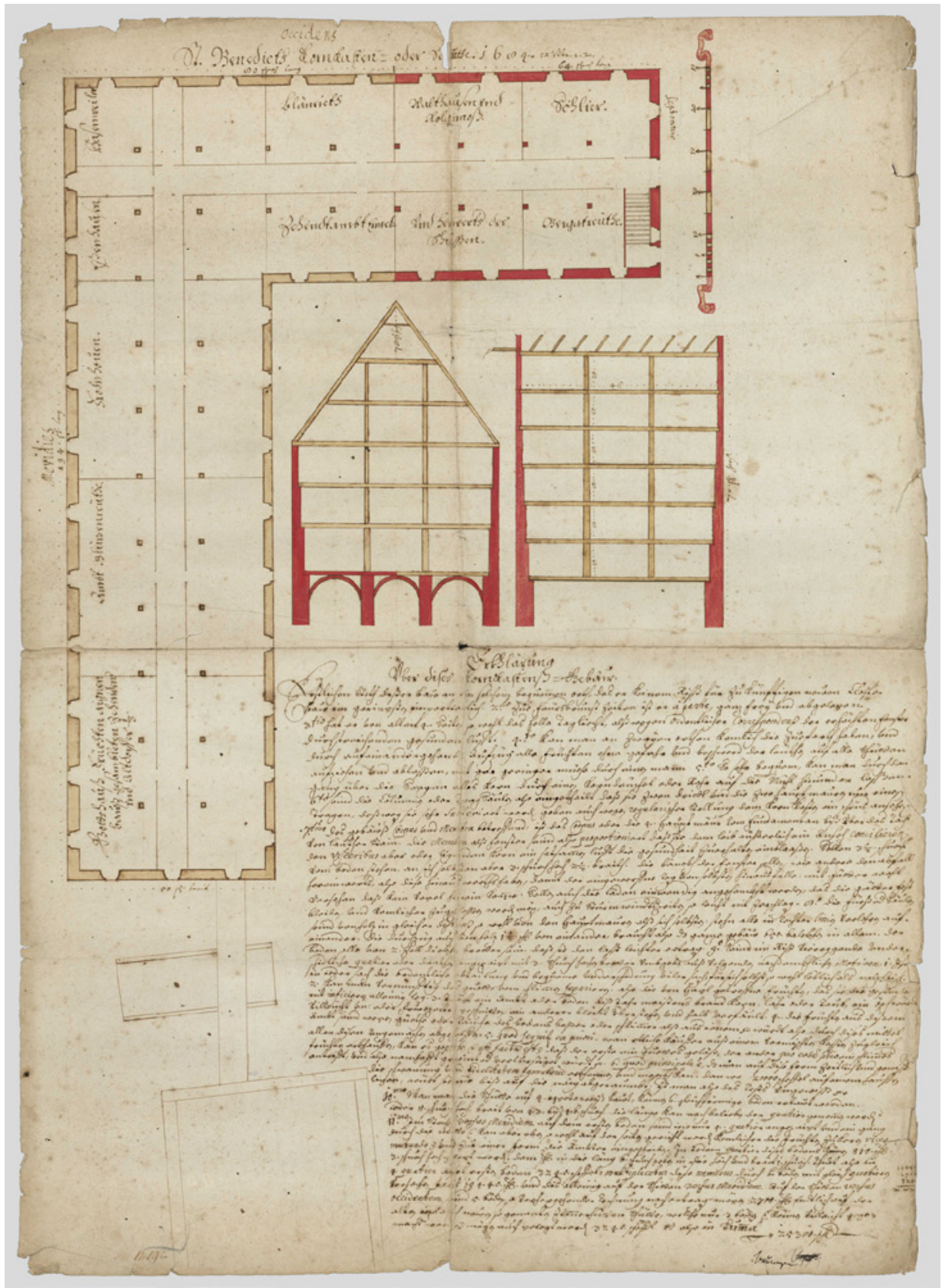

FIGURE 1.1 Architectural sketch of granary (Fruchtkasten) of the Weingarten Monastery from the year 1684 HAUPTSTAATSARCHIV STUTTGART, B 522 BÜ 69 PLAN; RELEASED FOR PUBLICATION AZ. 7-W 41-20170122 
values published so far - assuming that Roman horrea only had one storage floor as proposed in the models cited at the beginning of this chapter. Thus, the storage capacity of the Voerendaal granary (cat. 33) was between $208.2 \mathrm{~m}^{3}$ and $268.72 \mathrm{~m}^{3}$. This corresponds to $69.4 \%$ and $89.57 \%$ respectively of Willem $\mathrm{H}$. Willems' minimum storage capacity and $52.05 \%$ and $67.18 \%$ of the maximum storage capacity of the Voerendaal granary (Willems 1988). The military granaries from Roman Britain had only between $27.76 \%$ and $35.83 \%$ of the capacity presumed by Anne Gentry (1976).

But it must be asked whether Roman horrea actually had only one storage floor or whether some granaries might have had two. In south-west Germany, some excavations of villae have uncovered granaries whose walls had fallen down but with the masonry bond intact. These walls show that the Roman granaries could have had eave heights of more than $7 \mathrm{~m}$ (Blöck 2008, 157-59; Sommer 2005, 282-83). This means that Roman granaries could have had two storeys: a ground floor and a first floor, each with headroom corresponding to that of early modern granaries.

The existence of constructional elements such as deep foundations, very thick foundations and walls, pillars and the pilasters that most Roman granaries had, show that these were tall buildings (Blöck 2016, 96 note 590).

Horrea that did not have any substructures for a raised ground floor must have had a second floor that was used for the storage of grain. Ground floors without a raised floor were unsuitable for long-term grain storage because they were too damp and inadequately ventilated (Blöck 2016, 97 notes 592-93).

Horrea that have no substructures in the ground floor and that are well preserved show that the ground floors were not used for the storage of grain. The ground floor of the granary of the Bad Rappenau "Maueräcker" villa was used as a living space (Wulfmeier and Hartmann 2009, 347). On the ground floor of the double granary of the villa of Münzenberg-Gambach, three cellars were built, as well as a room with wickerwork walls used as a workshop (Rupp, Schmid, and Boenke 1998; Blöck 2016, 96 note 591).

Roman granaries that had substructures for a raised ground floor such as pillars or wall substructures (suspensurae) probably had two corn lofts: one on the raised and ventilated ground floor and one on the first floor. If one follows this reconstruction of horrea with suspensurae, the volume capacities of the military horrea from Roman Britain and the granary of the villa of Voerendaal are doubled. The granary of the Voerendaal villa would then have had a capacity of $416.41 \mathrm{~m}^{3}$ or $537.44 \mathrm{~m}^{3}$ respectively which is $138.8 \%$ or $179.15 \%$ of Willems' minimum and $104.1 \%$ or $134.36 \%$ Willems' maximum capacity (Willems 1988). The military horrea from Roman Britain would then have had $55.52 \%$ or $71.88 \%$ respectively of Gentry's capacity (Gentry 1976). 
With the data from Krünitz and the Weingarten monastery, we can calculate the storage capacity of a Roman granary in terms of volume. Each type of grain has its own density. Therefore the storage capacity in terms of weight of a Roman granary depends on the type of cereal cultivated and stored. To calculate a Roman granary's capacity in terms of weight, we need to know which cereals were cultivated and how much of each type was stored.

The three main cereals in Roman times in the province Germania superior were spelt, barley, and rye. Before the industrialization of German agriculture, densities with chaff were $39 \mathrm{~kg} / \mathrm{hl}$ for spelt, $58 \mathrm{~kg} / \mathrm{hl}$ for (winter) barley, and $68 \mathrm{~kg} / \mathrm{hl}$ for rye (Scherer 1969, 74).

The problem is that we need archaeobotanical data from a villa to know which cereals were stored in a Roman granary. To obtain such data, good preservation of features is necessary. But even allowing for optimum conditions during excavation, we cannot know for sure the different proportions of the stored cereals. As a consequence, to reconstruct the different proportions we must draw on more or less reliable estimates.

To model the areas necessary to cultivate the quantity of grain that can be stored in a granary, two further parameters must be known: the seed/crop yield ratio and the quantity of seed.

In the research literature on yields in ancient agriculture, these values vary greatly (Lang 2009, 393-402). Recent studies of ancient seed yield ratios presume ratios of 5:1 (five grains harvested for one sown) and 10:1 (ten harvested for one sown) respectively. But yield ratios that reach values like 10:1 are too high. Medieval and early modern sources from south-west Germany show that 10:1 yield ratios were only reached in areas with high-quality soils under special circumstances in pre-industrial grain production (Blöck 2016, 100-101 note 618). In most cases the ratio was $5: 1$ or even less. Since both the medieval/early modern and the Roman styles of agriculture were traditional, it is doubtful that Roman agriculture was more productive than medieval and early modern agriculture. I therefore use a yield ratio of 5:1 for my calculation.

To calculate the crop yields in the Roman north-western provinces, the existing literature often relies on information from Columella's Agriculture about seed quantities. But Columella writes about agriculture in Roman Italy and his values for the quantity of seed differ considerably from the values we know for medieval and early modern Germany (Lang 2009, 399-400).

The quantity of seed was stable in agriculture in Germany from medieval times until the industrial revolution in the nineteenth century (Boelcke 1964, 264; Lüning and Meurers-Balke 1980, 331). Hence, it makes more sense, in my opinion, to rely on the quantity of seed we know from medieval/early modern 
agriculture in Germany, particularly since the same sowing technique was used during this period and in Antiquity (Lang 2009, 397).

For the three main cereals of Roman Germany - spelt, barley, and rye - we know the following quantities of seed from late medieval/early modern sources: spelt with chaff 164.4-219.2 kg per hectare (Blöck 2016, 101 note 624), barley $147 \mathrm{~kg}$ per hectare (Lüning and Meurers-Balke 1980, 330 fig. 14), and rye 143.3$181 \mathrm{~kg}$ per hectare (Blöck 2016, 101 note 626).

As a case study, the storage capacities of the granaries of two Gallo-Roman villae are calculated. Based on this data, the cultivation areas are estimated that were needed to produce the quantity of grain to match the capacities of the granaries (tab. 1). Because there are two different values for storage capacities - the Krünitz storage capacity and the Weingarten granary capacity - and because we have differing values for the quantities of seed, four different values can be calculated for the storage capacity and therefore also for the cultivation areas. These values should not be interpreted as indisputable reconstructions of the cereal area but as model calculations of the maximum cultivation areas of cereals for these villae. It is also important to emphasize that no one calculated value has a higher probability than the other three values.

Calculations are based on assumptions that cannot be verified with the present data: the values for the quantities of seed and the seed crop yield ratios are not based on historical or archaeological sources pertaining to the research area in Roman times.

Furthermore we do not know which other crops, such as legumes and fruits, or which goods, such as amphoras or agricultural equipment, were stored in the granaries (Gentry 1976, 16; Wulfmeier and Hartmann 2009, 350). Thus we do not know how much space in the granaries was actually for the storage of grain. For example, in the horreum of the Biberist "Spitalhof" villa not only grain, but fruits, nuts, and legumes were stored, as shown by the archaeobotanical analysis (Jacomet and Petrucci-Bavaud in Schucany 2006, 590-94).

On the other hand, calculations are based on economic determinants and economic constants that can be established for pre-industrial agriculture in south-west Germany and that did not alter over the course of the centuries, such as the way grain was stored, the quantities of seed and the yield ratios. Moreover, the building and maintenance of the horrea were high cost factors for a Roman villa, as we can learn from Roman written sources on agriculture (Col. 1.4.6-7; Var., R. 1.13.5-6). In my opinion, it is thus more than probable that the volume of ventilated storage capacity reflects the amount of crop that was expected to be harvested.

In Roman times, grain was cultivated in a two-field system (Kreuz 1994-1995, 81; Eck 2007, 214-15; Lang 2009, 400). This means that a field was cultivated one 
year, and left fallow the following year. Therefore, to obtain the agricultural area of a Roman villa, we must double its calculated cultivation area.

The first example for the model calculation is the Bad Rappenau "Maueräcker" villa (Wulfmeier and Hartmann 2009; Blöck 2016, 97 note 595; cat. 251). The villa lies about $6 \mathrm{o} \mathrm{km}$ north of Stuttgart in a fertile loess area in the Neckar valley. It had a granary with an inner surface area of $465.3 \mathrm{~m}^{2}$. The ground floor was not ventilated and was used as living quarters as the existence of hearths shows. Therefore we must assume that the horreum had a first floor which served for grain storage. If we take the Krünitz capacity the granary could have stored $2583.39 \mathrm{hl}$ of grain, if we take the Weingarten capacity the storage capacity was $3334.35 \mathrm{hl}$ of grain.

Archaeobotanical analysis shows that rye, barley, and spelt were stored in the granary (Rösch 2009). Because all three cereals appear in the same quantities in the archaeobotanical analysis, I have hypothetically assumed that each cereal made up a third of the storage weight.

If we take the Krünitz capacity of $555.21 \mathrm{l} / \mathrm{m}^{2}$ of grain, the granary could hold $1150.25 \mathrm{hl}(44,860 \mathrm{~kg})$ spelt, $773.45 \mathrm{hl}(44,860 \mathrm{~kg})$ barley, and $659.7 \mathrm{hl}$ $(44,86 \mathrm{o} \mathrm{kg})$ rye (tab. 1$)$. If we take the Weingarten capacity of $716.58 \mathrm{l}$ of grain per cubic metre, the granary could hold $1484.58 \mathrm{hl}(57,898 \mathrm{~kg})$ spelt, $998.24 \mathrm{hl}$ $(57,898 \mathrm{~kg})$ barley, and $851.44 \mathrm{hl}(57,898 \mathrm{~kg})$ rye. Depending on the estimated quantities of seed, we calculate cultivation areas between 151.53 and 230.02 ha in order to produce such quantities of grain. To determine the total agricultural area of the villa, we have to double the area under cultivation because of the two-field system. In the model, the agricultural area of the Bad Rappenau "Maueräcker" villa can thus be estimated at between 303.06 and 460.04 ha.

These values seem very high but we must consider that they have been calculated with maximum grain storage capacities. Since not only grain but also other goods were stored in the horreum, the actual grain capacities of the granary and thus the agricultural area of the villa of Bad Rappenau "Maueräcker" would have been lower. There is an archaeological study of the Roman colonization of the area in which the Bad Rappenau "Maueräcker" villa is situated (Hüssen 2000). Even if one fits the largest agricultural area of 460.04 ha into the Roman settlement landscape there are no overlaps with other villae (Hüssen 2000, Beilage Nr. 127 and 131). So even the largest calculated area cannot be ruled out.

The second example is the horreum of the Biberist "Spitalhof" villa - a double courtyard villa in today's Switzerland - beside the river Aare (cat. 85). During an expansion phase in the second century, a granary was built on the estate (tab. 1). The horreum had a ground floor with an area of $590 \mathrm{~m}^{2}$ that had pillars for a raised, ventilated storage floor (Schucany 2006, 187-97 and 222-23). 
TABLE 1.1 Villa Bad Rappenau "Maueräcker" and villa Biberist "Spitalhof”, capacity and agricultural area calculations

\section{Crop yield ratios 1:5 \\ minimum quantity of seed \\ Krünitz capacity 555,21 l// $\mathrm{m}^{2}$ \\ Crop yield ratios 1:5 maximum quantity of seed Krünitz capacity 555,21 1/m²}

storage capacity: $25^{83}, 39 \mathrm{hl}$ : $1150.25 \mathrm{hl}=44860 \mathrm{~kg}$ spelt $773.45 \mathrm{hl}=44860 \mathrm{~kg}$ barley storage
none storage area first floor:

$659 \cdot 7 \mathrm{hl}=44860 \mathrm{~kg}$ rye $659.7 \mathrm{hl}=44860 \mathrm{~kg}$ rye

54.57 ha spelt fields 40.93 ha spelt fields 61.03 ha barley fields 61.03 ha barley fields 62.61 ha rye fields 49.57 ha rye fields $=178.21$ ha cereal area $=151.53$ ha cereal area $=356.42$ ha agricultural area $=303.06$ ha agricultural area

\section{Biberist, Gebäude D} (period II / phase 3)

ventilated ground floor storage area ground floor: $590 \mathrm{~m}^{2}$

storage area first floor:

$590 \mathrm{~m}^{2}$

total storage area: $1180 \mathrm{~m}^{2}$

stored grains: spelt, barley storage capacity: $6551,48 \mathrm{hl} \quad$ storage capacity: $6551,48 \mathrm{hl}$

$$
3917 \cdot 38 \mathrm{hl}=15^{277} 8 \mathrm{~kg} \text { spelt }
$$$$
2634.1 \mathrm{hl}=152778 \mathrm{~kg} \text { barley }
$$

$3917 \cdot 38 \mathrm{hl}=152778 \mathrm{~kg}$ spelt $2634.1 \mathrm{hl}=15^{2} 778 \mathrm{~kg}$ barley
185,86 ha spelt fields 207,86 ha barley fields $=393,72$ ha cereal area

$=787.44$ ha agricultural area
139,4 ha spelt fields 207,86 ha barley fields $=694.5^{2}$ ha agricultural area $=347,26$ ha cereal area 
Crop yield ratios 1:5 minimum quantity of seed Weingarten capacity $716,5^{81} / \mathrm{m}^{2}$

storage capacity: 3334,25 hl:

$1484.58 \mathrm{hl}=57898 \mathrm{~kg}$ spelt

$998.24 \mathrm{hl}=57898 \mathrm{~kg}$ barley

$851.44 \mathrm{hl}=57898 \mathrm{~kg}$ rye

70.44 ha spelt fields

78.77 ha barley fields

80.81 ha rye fields

$=230.02$ ha cereal area

$=460,04$ ha agricultural area

storage capacity: $8455,64 \mathrm{hl}$

$5055.95 \mathrm{hl}=197182 \mathrm{~kg}$ spelt

$3399.69 \mathrm{hl}=197182 \mathrm{~kg}$ barley

239.88 ha spelt fields

268.27 ha barley fields

$=508.15$ ha cereal area

$=1016.3$ ha agricultural area

\section{Crop yield ratios 1:5}

maximum quantity of seed

Weingarten capacity $716,5^{8} \mathrm{l} / \mathrm{m}^{2}$

storage capacity: 3334,25 hl:

$1484.58 \mathrm{hl}=57898 \mathrm{~kg}$ spelt

$998.24 \mathrm{hl}=57898 \mathrm{~kg}$ barley

$851.44 \mathrm{hl}=57898 \mathrm{~kg}$ rye

$5^{2.83}$ ha spelt fields

78.77 ha barley fields

63.98 ha rye fields

$=195.58$ ha cereal area

$=391.16$ ha agricultural area

storage capacity: $8455,64 \mathrm{hl}$

$5055.95 \mathrm{hl}=197182 \mathrm{~kg}$ spelt

$3399.69 \mathrm{hl}=197182 \mathrm{~kg}$ barley

179.91 ha spelt fields

268.27 ha barley fields

$=448.18$ ha cereal area

$=896.36$ ha agricultural area 
Assuming that the granary had two storeys, it had a grain storage area of $1180 \mathrm{~m}^{2}$. According to the archaeobotanical analysis of the granary, the cereals stored were mainly barley and spelt (Jacomet and Petrucci-Bavaud in Schucany 2006, 590-94). For the model calculation, I have assumed that barley and spelt each made up half of the storage weight. In this case the granary could hold, after Krünitz, 3917.38 hl (152,778 kg) of spelt and $2634.1 \mathrm{hl}(152,778 \mathrm{~kg})$ of barley, and after Weingarten, $5055.95 \mathrm{hl}(197,182 \mathrm{~kg})$ of spelt and $3399.69 \mathrm{hl}$ $(197,182 \mathrm{~kg})$ of barley. Depending on the supposed quantities of seed, we get values between 347.26 ha and 508.15 ha for the cultivation area, and between $694.5^{2}$ ha and 1016.3 ha for the agricultural area. The enormous storage capacity indicates that not only the estate's own harvest was stored in the villa of Biberist-Spitalhof, but the yield of several villae, which was already presumed by Caty Schucany - although on the assumption that the granary had an even higher storage capacity (Schucany 2006, 197). The phenomenon whereby one villa had access to the yields of other villae can be observed at other villae in the Germanic provinces. In the course of the second and third centuries there were processes of economic concentration in the rural landscape that led to increased economic and social power of some villae at the expense of others (Blöck 2011-2012, 108-9, 2016, 108-9).

To conclude, I would like to emphasize some crucial points. The model presented for the calculation of the storage capacity of Roman horrea here has many limitations as set out above. Nevertheless, it can give some idea of the amounts of grain that were at the disposal of a Roman villa.

The calculations of the agricultural areas are based on even more assumptions that cannot be proved. They are proposed only as tentative approaches to determining the dimensions of the agricultural areas necessary for the production of the stored grain. Furthermore, the calculated agricultural areas are not to be equated with the fundus of a villa. A fundus included not only fields but also woods, grassland, and other areas.

Finally, the model calculations are based on data that were extracted from sources that refer to pre-industrial agriculture in what is now Germany, and especially south-west Germany. The calculations therefore are valid for this particular region. In areas with different soil and climate conditions or different agricultural traditions appropriate datasets would be needed for such capacity calculations. 